\title{
Platinum Plus Gemcitabine as the Most Effective Regimen in the First Line of Chemotherapy in Advanced Squamous Cell Lung Cancer
}

\author{
Villa JC*, Espinosa J, López R, Galan R, Sanchez V, Cervera R, Gómez R. \\ Department of Medical Oncology, General University of Ciudad Real, Spain \\ *Correspondence to: Villa JC, Department of Medical Oncology, General University of Ciudad Real, Spain; E-mail id: jvillaguzman1@yahoo.es;
}

Received: January 18, 2017; Accepted: February 08, 2017; Published: April 24, 2017;

\begin{abstract}
Purpose: Platinum-based doublet chemotherapy had been the standard first-line treatment for advanced NSCLC, regardless of histologic subtypes. We report overall survival (OS) and time to treatment failure (TTF) in patients with squamous cell lung cancer (SCC) receiving doublet of platinum.

Patients and methods: Patients $(\mathrm{N}=82)$ with advanced NSCLC received doublet of platinum. Sixty five $(79,2 \%)$ patients were treated with a combination of platinum plus gemcitabine and $17(20,7 \%)$ received microtubules inhibitor ( 3 patients were treated with vinorelbine, 3 patients with docetaxel and 11 patients with paclitaxel).
\end{abstract}

Results: Median TTF was 2,53 months $\mathrm{CI}_{95 \%}[2,21-2,84]$ and median OS was 8,246 months $\mathrm{CI}_{95 \%}[5,8-2,6]$. Regarding doublet of chemotherapy, in patients in which gemcitabine was used there was an improvement in TTF of 1,2 months ( $p=0,107$; log rank) and 4,75 months in OS ( $p=0,018$; log rank).

Conclusion: Gemcitabine plus platinum must be the chemotherapy of ghoice in advanced SCC. Randomized clinical trials with gemcitabine in advanced SCC are needed.

Keywords: squamous cell lung cancer, chemotherapy, gemcitabine

\section{Introduction}

Primary lung cancer is the most common malignancy and the first death related causes from cancer in the worldwide. Nowadays, it is the most important cause of cancer mortality in men and women. Lung cancer is still increasing both in incidence and mortality worldwide. In Spain, more than 21,000 men were diagnosed of lung cancer in 2012, while over 17,000 died. Lung cancer is the leading cause of dead among Spanish men. Figures in women were near 5,000 and more than 3,500 respectively. Women got into the habit of smoking some decades later than men in Spain [1]. Non-small-cell lung cancers (NSCLC) account for $85 \%-90 \%$ of lung cancers. NCSLC includes several histologic subtypes such as adenocarcinoma, squamous cell carcinoma (SCC), and large cell carcinoma. Platinum-based doublet chemotherapy had been the standard first-line treatment for advanced NSCLC, regardless of histologic subtypes [2].

New agents has been developed recently (anti folate, anti VEGF, antiEGFR, etc) [3]. These agents play a crucial role in first-line systemic therapy for nonsquamous histology while they do not have activity in SCC.

On the other hand, several regimens of platinum-based doublet chemotherapy are currently the standard first-line therapy for advanced lung SCC, including platinum combined with gemcitabine, docetaxel, paclitaxel, or vinorelbine and these scheludes have similar effectiveness [4].

There are not any phase III studies focused on determining what is the most active platinum-based chemotherapy regimen to treat advanced lung SCC. This study examined the comparative effectiveness of various platinum-based regimens as first-line therapy for advanced lung SCC.

\section{Material and methods}

\section{Patients}

This is a retrospective study. The study population included patients with newly diagnosed lung SCC from 2012 to 2014 in the University General Hospital of Ciudad Real (Spain). The following inclusion criteria were used to identify eligible patients: (1) pathologically proven initial diagnosis of lung SCC as the single primary cancer; (2) age $\geq 18$ years; and (3) advanced disease stage at diagnosis, which was defined as stage IIIB or stage IV disease according to the American Joint Committee on Cancer, 7 th edition. ${ }^{5}$ Patients who underwent surgery during the first course of treatment and those who underwent radiotherapy with curative intent (which was defined as a cumulative dose > 50 Gy) were excluded.

All patients received chemotherapy for advanced lung SCC. Main regimens considered in our study including cisplatin $(\mathrm{P})$, carboplatin $(C P)$, gemcitabine $(G)$, docetaxel $(D)$, paclitaxel $(T)$, or vinorelbine (V). Platinum agent was considered and patients were classified into patients who received cisplatin or carboplatin.

\section{Objective}

The main objective was overall survival (OS). OS was determined according to the date of diagnosis of advanced lung SCC to the date of death. 


\section{Statistical analysis}

Baseline demographic and clinical variables were summarized with descriptive statistics. Regard chemotherapy, G were recoded as antimetabolite and D, T, V as microtubules inhihitor (MI).

The OS was estimated using the Kaplan-Meier method, and the differences between the study groups were compared using the logrank test. The Cox proportional hazard model was used to estimate the univariate or adjusted hazard ratios and associated $95 \%$ confidence intervals for detecting differences in the effects of treatments on overall mortality. The sex, age, brain metastases and type of platinum were adjusted in the Cox proportional hazard model. Subgroup analyses defined according to sex, age $(<70$ or $\geq 70$ years $)$ and platinum were performed as sensitivity analyses to determine whether the differences in effects on mortality of platinum + antimetabolite compared with those of $\mathrm{P}+\mathrm{MI}$. Two-sided $P$ values of $\leq .05$ were considered statistically significant. All analyses were performed by SPSS for windows v. 18.

\section{Results}

\section{Baseline characteristics}

Eighty two patients were included in this study. Among them, 79 (96.3\%) were men, 41 (50\%) were aged $\geq 70$ years, and $2(2,7 \%)$ had brain metastases (Table 1). Sixty five $(79,2 \%)$ patients were treated with a combination of platinum plus gemcitabine and 17 $(20,7 \%)$ received microtubules inhibitor (3 patients were treated with vinorelbine, 3 patients with docetaxel and 11 patients with paclitaxel). Patients aged $<70$ years were more likely to receive chemotherapy with microtubules inhibitors than older patients (70,6\% vs. 44,6\%, $P=$ $0.057)$. Up to December the 31 th, 2014,66 patients $(80,5 \%)$ were with progression disease, $68(82,2 \%)$ had died and 45 patients $(54,9 \%)$ were controlled by the Palliative Care Unit. The median follow-up time was 6 months (table 1).

In patiens, the main causes of death were progression disease in 59 patients $(86,7 \%)$, pulmonary embolism in 2 patients $(2,9 \%)$, stroke in 1 patient $(1,47 \%)$, chronic obstructive pulmonary disease in 3 patients $(4,4 \%)$, myocardial infarction in 1 patient $(1,47 \%)$, hemoptysis in 1 patient $(1,47 \%)$ and chemotherapy related toxicity in 1 patient $(1,47 \%)$ (Figure 1).

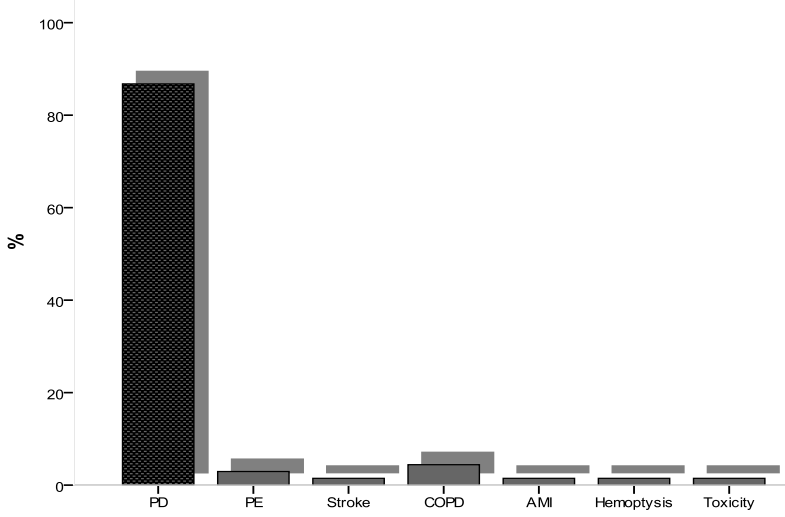

Figure 1. main causes of death of patients.
Table 1: Baseline characteristics of patients with advanced lung squamous cell carcinoma in our series.

\begin{tabular}{|c|c|c|c|c|}
\hline $\begin{array}{c}\text { Baseline } \\
\text { Characteristics }\end{array}$ & Gemcitabine & $\begin{array}{l}\text { Microtubule } \\
\text { inhibitor }\end{array}$ & All & p \\
\hline $\mathrm{N}(\%)$ & $65(79,2 \%)$ & $17(20,7 \%)$ & $82(100 \%)$ & \\
\hline Age (median, range) & $71(44-88)$ & $64(40-81)$ & $70(40-84)$ & 0,118 \\
\hline $\begin{array}{l}\text { Years }(\mathrm{n}, \%) \\
<70 \text { años } \\
>70 \text { años }\end{array}$ & $\begin{array}{l}29(44,6) \\
36(55,4)\end{array}$ & $\begin{array}{r}12(70,6) \\
5(29,4)\end{array}$ & $\begin{array}{l}41(50,0) \\
41(50,0)\end{array}$ & 0,057 \\
\hline $\begin{array}{l}\text { Gender }(\mathrm{n}, \%) \\
\text { Male } \\
\text { Female }\end{array}$ & $\begin{array}{c}63(96,9) \\
2(3,1)\end{array}$ & $\begin{array}{c}16(94,1) \\
1(5,9)\end{array}$ & $\begin{array}{c}79(96,3) \\
3(3,7)\end{array}$ & 0,583 \\
\hline $\begin{array}{l}\text { Brain Metastases (n, \%) } \\
\text { No } \\
\text { Yes }\end{array}$ & $\begin{array}{c}63(96,9) \\
2(3,1)\end{array}$ & $\begin{array}{c}17(100,0) \\
0(0,0)\end{array}$ & $\begin{array}{c}80(97,6) \\
2(2,4)\end{array}$ & 0,464 \\
\hline $\begin{array}{l}\text { Platinium (n,\%) } \\
\text { Cisplatin } \\
\text { Carboplatin }\end{array}$ & $\begin{array}{l}21(32,3) \\
44(67,7)\end{array}$ & $\begin{array}{r}3(17,6) \\
14(82,4)\end{array}$ & $\begin{array}{l}24(29,3) \\
58(70,7)\end{array}$ & 0,237 \\
\hline $\begin{array}{l}\begin{array}{l}\text { Progression first line } \\
(\mathrm{n}, \%)\end{array} \\
\text { No } \\
\text { Yes }\end{array}$ & $\begin{array}{l}11(16,9) \\
54(83,1)\end{array}$ & $\begin{array}{r}5(29,4) \\
12(70,6)\end{array}$ & $\begin{array}{l}16(19,5) \\
66(80,5)\end{array}$ & 0,247 \\
\hline $\begin{array}{l}\text { Second line (n, \%) } \\
\text { Taxanes } \\
\text { Gemcitabine } \\
\text { TKI }\end{array}$ & $\begin{array}{c}27(41,5) \\
21(77,7) \\
0(0,0) \\
6(22,2)\end{array}$ & $\begin{array}{l}4(23,5) \\
2(50,0) \\
1(25,0) \\
1(25,0)\end{array}$ & $\begin{array}{c}31(37,8) \\
23(74,19) \\
1(3,3) \\
7(22,5)\end{array}$ & 0,173 \\
\hline $\begin{array}{l}\text { Control by Palliative } \\
\text { Care Unit }(\mathrm{n}, \%) \\
\text { No } \\
\text { Yes }\end{array}$ & $\begin{array}{l}29(44,6) \\
36(55,4)\end{array}$ & $\begin{array}{l}8(47,1) \\
9(52,9)\end{array}$ & $\begin{array}{l}37(45,1) \\
45(54,9)\end{array}$ & 0,857 \\
\hline $\begin{array}{l}\text { Estatus } \\
\text { Alive } \\
\text { Exitus }\end{array}$ & $\begin{array}{l}12(18,5) \\
53(81,5)\end{array}$ & $\begin{array}{c}2(11,8) \\
12(88,2)\end{array}$ & $\begin{array}{l}14(17,1) \\
68(82,9)\end{array}$ & 0,514 \\
\hline
\end{tabular}

\section{Time to treatment failure}

Median TTF was 2,53 months $\mathrm{CI}_{95 \%}$ [2,21 - 2,84] (Figure 2). Considering age, sex, brain metastases, platinum compound and doublet of chemotherapy, we did not find differences (Table 2). Regarding doublet of chemotherapy, in patients in which gemcitabine was used there was an improvement in TTF of 1.2 months ( $p=0.107$, log rank) (Figure 3).

\section{Overall survival}

Median OS was 8,246 months $\mathrm{CI}_{95 \%}[5,8-2,6]$ in all patients (Figure 4). Overall survival rate al 6, 12 and 18 months were $62,8 \%, 35,1 \%$ and $3,8 \%$ respectively. Considering age, sex, brain metastases, platinum compound and doublet of chemotherapy there were statistically significant differences regard sex and doublet of CT (Table 3).

In multivariate analyses adjusted for sex, age $(<70$ or $\geq 70$ years) and platinium the first line chemotherapy regimen based in antimetabolites was a predictor of OS $(\mathrm{p}=0.018)$. 
Villa JC (2017) Platinum Plus Gemcitabine as the Most Effective Regimen in the First Line of Chemotherapy in Advanced Squamous Cell Lung Cancer

Table 2: Medians and hazard ratios of time to treatment failure regarding age, sex, brain metastases, platinum compound and doublet of chemotherapy.

\begin{tabular}{|l|l|l|l|l|}
\hline & $\begin{array}{l}\text { Median } \\
\text { months, } \mathbf{I C}_{95 \%}\end{array}$ & $\begin{array}{l}\mathbf{P , ~ l o g} \\
\text { rank }\end{array}$ & $\begin{array}{l}\text { Hazard ratio, } \\
\mathbf{I C}_{95 \%}\end{array}$ & $\mathbf{P , ~ c o x}$ \\
\hline $\begin{array}{l}\text { Age } \\
<70 \text { años } \\
>70 \text { años }\end{array}$ & $\begin{array}{l}2,9[2,07-3,9] \\
2,3[2,1-2,5]\end{array}$ & 0,264 & $0,757[0,46-1,24]$ & 0,269 \\
\hline $\begin{array}{l}\text { Sex } \\
\text { Male } \\
\text { Female }\end{array}$ & $\begin{array}{l}2,5[2,2-2,8] \\
1,9[0,0-5,04]\end{array}$ & 0,714 & $0,806[0,25-2,6]$ & 0,718 \\
\hline $\begin{array}{l}\text { Brain Metastases (n, \%) } \\
\text { No }\end{array}$ & $2,5[2,1-2,8]$ \\
Yes & $2,3[$ n.r. $]$ & 0,771 & $0,747[0,1-5,5]$ & 0,774 \\
\hline $\begin{array}{l}\text { Platinum (n,\%) } \\
\text { Cisplatin } \\
\text { Carboplatin }\end{array}$ & $\begin{array}{l}2,3[2,01-2,7] \\
2,6[1,9-3,2]\end{array}$ & 0,895 & $1,037[0,6-1,7]$ & 0,896 \\
\hline $\begin{array}{l}\text { Doublet of CT (n, \%) } \\
\text { Microtubules inhibitor } \\
\text { Gemcitabine }\end{array}$ & $\begin{array}{l}1,7[0,0-4,3] \\
2,5[2,2-2,8]\end{array}$ & 0,107 & $1,677[0,8-3,1]$ & 0,115 \\
\hline
\end{tabular}

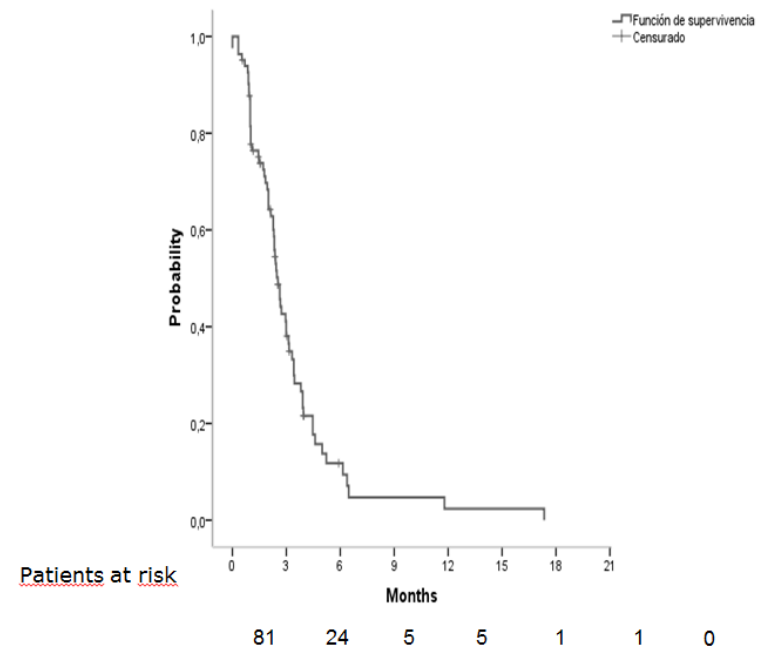

Figure 2. Median time to treatment failure in all patients.

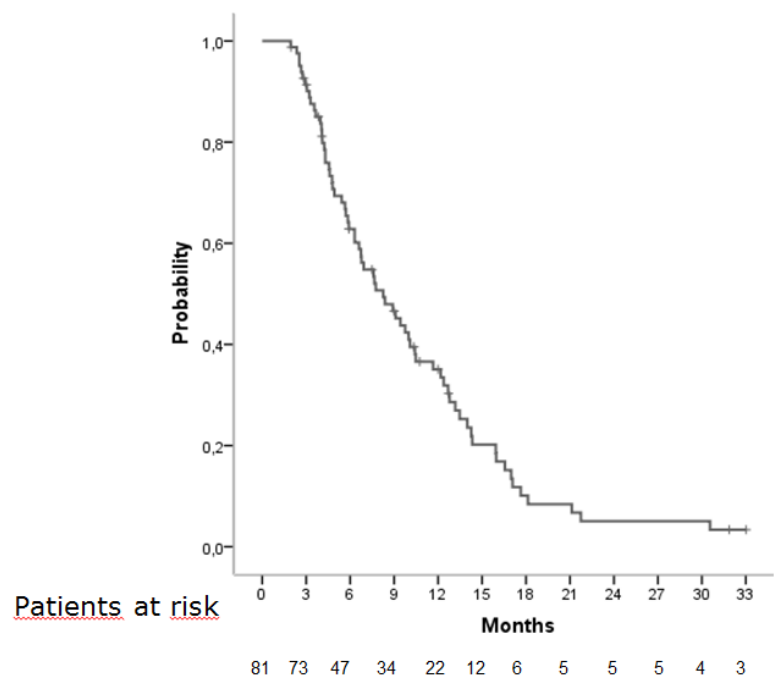

Figure 4. Overall survival in all patients.
Table 3: Medians and hazard ratios of time to treatment failure regarding age, sex, brain metastases, platinium compound and doublet of chemotherapy.

\begin{tabular}{|l|l|l|l|l|}
\hline & $\begin{array}{l}\text { Median } \\
\text { months, } \mathbf{I C}_{\mathbf{9 5} \%}\end{array}$ & $\begin{array}{l}\text { P, log } \\
\text { rank }\end{array}$ & $\begin{array}{l}\text { Hazard ratio, } \\
\text { IC }_{95 \%}\end{array}$ & P, cox \\
\hline $\begin{array}{l}\text { Age } \\
<70 \text { años } \\
>70 \text { años }\end{array}$ & $\begin{array}{l}7,5[4,6-10,5] \\
8,9[6,4-11,3]\end{array}$ & 0,619 & $0,884[0,54-1,43]$ & 0,619 \\
\hline $\begin{array}{l}\text { Sex } \\
\text { Male } \\
\text { Female }\end{array}$ & $\begin{array}{l}8,3[6,2-10,5] \\
3,2[2,4-4,1]\end{array}$ & 0,006 & $\begin{array}{l}0,217 \quad[0,06- \\
0,719]\end{array}$ & 0,012 \\
\hline $\begin{array}{l}\text { Brain Metastases (n, \%) } \\
\text { No } \\
\text { Yes }\end{array}$ & $\begin{array}{l}8,2[5,8-10,6] \\
4,3[n . r .]\end{array}$ & 0,596 & $1,466[0,35-6,1]$ & 0,599 \\
\hline $\begin{array}{l}\text { Platinium (n,\%) } \\
\text { Cisplatin } \\
\text { Carboplatin }\end{array}$ & $\begin{array}{l}10,48 \\
17,02] \\
7,65[4,9-10,33]\end{array}$ & 0,260 & $0,764[0,42-1,2]$ & 0,263 \\
\hline $\begin{array}{l}\text { Doublet of CT (n, \%) } \\
\text { Microtubules inhibitor } \\
\text { Gemcitabine }\end{array}$ & $\begin{array}{l}5,7[3,8-7,6] \\
9,45[6,7-12,1]\end{array}$ & 0,018 & $1,989[1,1-3,5]$ & 0,021 \\
\hline
\end{tabular}

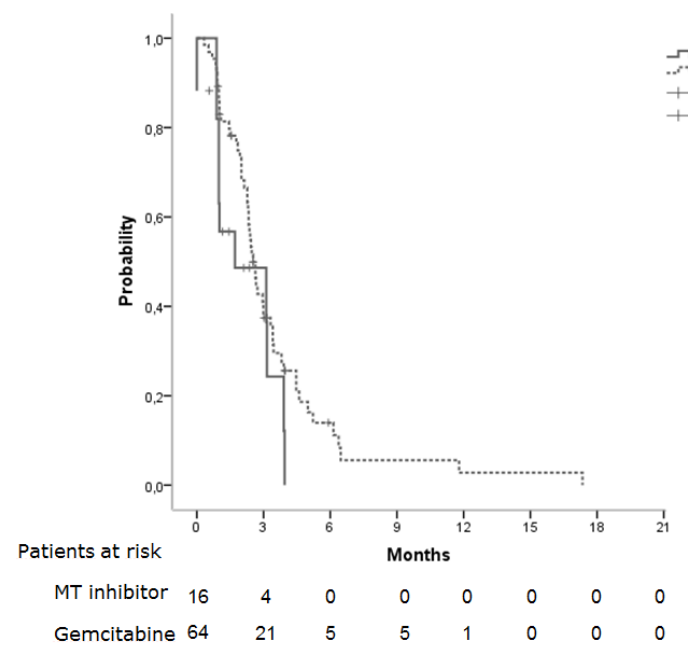
Microtubule inhibitorGencirabine-censured

Figure 3. Time to treatment failure regarding doublet of chemotherapy.

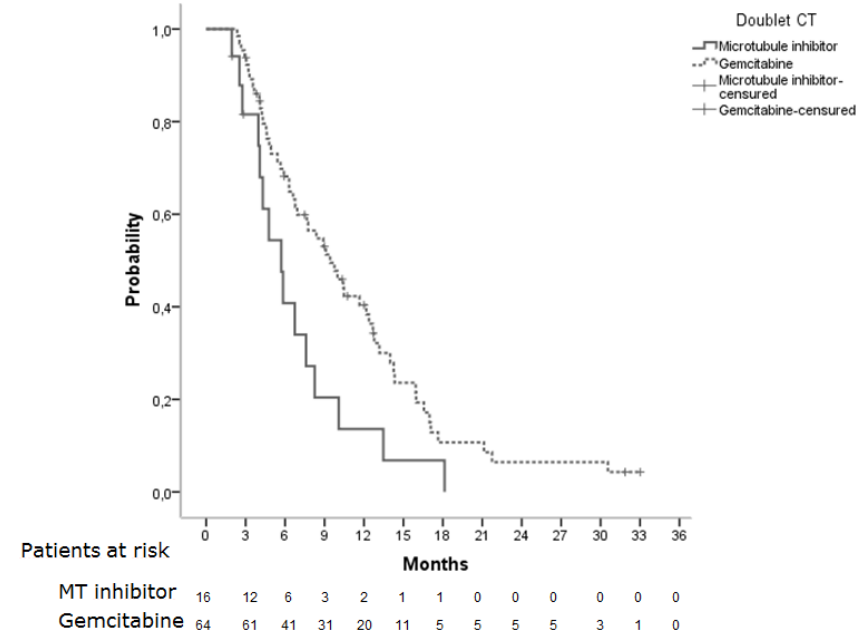

Figure 5. Overall survival according doublet of chemotherapy. 


\section{Second line}

Only $31(37,8 \%)$ patients received second line therapy of treatment. Most common agents were docetaxel (17 patients, 54,8\%), paclitaxel (6 patients, 19,9\%), erlotinib (6 patients, 19,4\%), gefitinib (1 patient, $3,2 \%)$ and gemcitabine (1 patient, 3,2\%).

Median OS posprogression (OSpp) was 6,637 months $\mathrm{CI}_{95 \%}$ $[5,4-7,8]$. With respect to type of treatment, patients treated with docetaxel had a median of 9,01 months $\mathrm{CI}_{95 \%}[5,1-12,9]$, patients treated with paclitaxel 6,6 months $\mathrm{CI}_{95 \%}[0,5-12,7]$ and patients treated with erlotinib 5,8 months $\mathrm{CI}_{95 \%}[4,6-7,1]$. Patient treated with gefitinib and gemcitabina were alive while 5,4 months and 3,2 months respectively. There were statistically significant differences in median OSpp regarding type of treatment ( $\mathrm{p}=0,026 \log$ rank). Hazard ratio for use of taxanes was $0,695, \mathrm{CI}_{95 \%}[0,26-1,83], \mathrm{p}=0,4$.

\section{Discussion}

Squamous cell NSCLC is a particularly aggressive type of lung cancer, and few treatments are effective [6]. The NCCN and ESMO frontline recommendations include chemotherapy doublets, which are considered the cornerstone of initial therapy for squamous NSCLC $[7,8]$. To our knowledge, no prospective clinical trial has specifically compared cytotoxic chemotherapies for advanced lung SCC so there is is uncertainty about the best option of treatment.

Respect gender, women is represented in 3,7\% in our study. In most published studies, little is reported about women diagnosed of advanced squamous NCSLC treated with CT. Overall survival among women in our study is poor (3,2 months versus 8,3$)$. Recently, it has been described that females patients with squamous NCSLC had a significantly higher rate of human papillomavirus (HPV) infection compared to males with SCC [9] and HPV infection appears to be involved in cancer progression in SCC by promoting the expression of p53. On the other hand, patterns of mutation in SCC are unknown being KRAS, FGFR1 and PIK3CA most frequently reported and women seem to have less PIK3CA mutation than men. Moreover, there may exist unknown endocrine mechanisms this particularly lack of response and bad prognosis in women. To our knowledge, there are no differences in smoking patters that could explain this fact [10].

Elderly and young patients, defined by $>70$ years or $<70$ years, have similar proportion in our series. Although doublets with microtubule inhibitors are less used in old patients overall survival is similar in both groups. The definition of elderly patients varies widely across trials and and an uniform definition is lacking. Particularly in the actual world setting, older patients are often untreated even even when free of comorbid illnesses. Most studies in advanced NSCLC define elderly patients as those older than 70 years for the treatment of advanced NSCLC [11] and the benefit of platinum-based doublet regimens in this population seems to be greater than single-agent chemotherapy. So avoiding the use of doublets in elderly is not justified in absence of comorbid status. Studies in elderly patients show similar response rates than in younger ones even with aggressive regimens of chemotherapy.

Palliative Care Unit (PCU) has played a preeminent role in the management of patients. More than half of our patients were remitted to PCU (45 patients, 54,9\%) This fact allowed better control of symptoms, especially at home, and ultimately improved patients' quality of life [12]. Early integration of palliative care into the treatment strategy should be mandatory because it may improve quality of life, particularly end-of-life care and improve overall survival. Our institution is working to make success this target.

Median time to treatment failure was 2,53 months and overall survival 8,24 months. The use of cisplatin or carboplatin has no impact on TTF or on OS, although use of cisplatin has a tendency to improve overall survival in 3 months over the use of carboplatin. Our data are similar to the reported about Veterans Health Administration data [12]. The use of gemcitabine as platinum doublet has demonstrated increased survival in our patients over microtubule inhibitors $(9,45$ months versus 4,7 months). A phase III trial of cisplatin and pemetrexed compared with cisplatin and gemcitabine revealed a statistically significant improvement in OS with cisplatin and gemcitabine in patients with squamous cell histology (10.8 vs 9.4 months) [13,14]. A retrospective study in patients with advanced lung SCC, revealed the use of various regimens did not have a significant effect on survival outcomes [15].

Finally, 31 patients $(37,8 \%)$ received second line of treatment being docetaxel the most common agent used in this setting followed by paclitaxel and erlotinib. Although the number of patients is small, there is an improvement in survival in the group treated with taxanes respect to the group treated with tyrosine kinase inhibitor TKI). In TITAN phase III study, [16] patients were randomized to receive TKI or CT (taxanes or pemetrexed) and both treatments were similar in efficacy with different toxicity profiles.

We conclude that gemcitabine must be the CT of choice in advanced SCC. On the other hand, female patients had worse prognosis, patients aged $>70$ years old must receive a double of platinum, cisplatin is similar to carboplatin and cisplatin must be used when there is no contraindication for its use. Aditional agents and strategies must be developed in this setting to improve quality of life and survival.

\section{References}

1. Ferlay J, Steliarova-Foucher E, Lortet-Tieulent J, Rosso S, Coebergh JW, et al. (2013) Cancer incidence and mortality patterns in Europe: estimates for 40 countries in 2012. Eur J Cancer 49: 1374-1403. [crossref]

2. Le Chevalier T, Scagliotti G, Natale R, Danson S, Rosell R, et al. (2005) Efficacy of gemcitabine plus platinum chemotherapy compared with other platinum containing regimens in advanced non-small-cell lung cancer: a meta-analysis of survival outcomes. Lung Cancer 47: 69-80.

3. Reck M, Popat S, Reinmuth N, De Ruysscher D, Kerr KM, et al. (2014) Metastatic non-small-cell lung cancer (NSCLC): ESMO Clinical Practice Guidelines for diagnosis, treatment and follow-up. Ann Oncol 25 Suppl 3: iii27-39. [crossref]

4. Schiller JH, Harrington D, Belani CP, et al. (2002) Comparison of four chemotherapy regimens for advanced non small-cell lung cancer. $N$ Engl J Med 346: 92-8.

5. Edge SB, Compton CC (2010) The American Joint Committee on Cancer: the 7th edition of the AJCC cancer staging manual and the future of TNM. Ann Surg Oncol 17: 1471-1474. [crossref]

6. McKeage MJ, Jameson MB, et al. (2010) Comparative outcomes of squamous and non-squamous non-small cell lung cancer (NSCLC) patients in phase II studies of ASA404 (DMXAA): retrospective analysis of pooled data. $J$ Thorac Dis 2:199-204.

7. Ettinger DS, Wood DE, Akerley W, Bazhenova LA, Borghaei H, et al. (2014) Nonsmall cell lung cancer, version 1.2015. J Natl Compr Canc Netw 12: 1738-1761. [crossref] 
8. Reck M, Popat S, Reinmuth N, De Ruysscher D, Kerr KM, Peters S (2014) ESMO Guidelines Working Group. Metastatic non-small-cell lung cancer (NSCLC): ESMO Clinical Practice Guidelines for diagnosis, treatment and follow-up. Ann Oncol 25 Suppl 3: iii27-39.

9. Fan X, Yu K, Wu J, Shao J, Zhu L, et al. (2015) Correlation between squamous cell carcinoma of the lung and human papillomavirus infection and the relationship to expression of p53 and p16. Tumour Biol 36: 3043-3049. [crossref]

10. Qiong Z, Na WY, Bo W2, Zhu Z, Ling P, et al. (2015) Alterations of a spectrum of driver genes in female Chinese patients with advanced or metastatic squamous cell carcinoma of the lung. Lung Cancer 87: 117-121. [crossref]

11. Owonikoko TK, Ramalingam SS2 (2015) Minimize toxicity or preserve efficacy? A delicate trade-off in the management of older patients with lung cancer. $J$ Clin Oncol 33: 534-536. [crossref]

12. Wagner B, Meffert C2, Becker G2 (2015) [Availability and integration of palliative medicine at certified lung cancer centers]. Pneumologie 69: 218-224. [crossref]
13. Santana-Davila R, Szabo A, Arce-Lara C, Williams CD, et al. (2014) Cisplatin versus carboplatin-based regimens for the treatment of patients with metastatic lung cancer. An analysis of Veterans Health Administration data. J Thorac Oncol 9: 702-9.

14. Scagliotti GV, Parikh P, von Pawel J, et al. (2008) Phase III study comparing cisplatin plus gemcitabine with cisplatin plus pemetrexed in chemotherapy-naive patients with advanced-stage non-small-cell lung cancer. J Clin Oncol 26:35433551.

15. Liao BC, Shao YY, Chen HM, Shau WY, Lin ZZ, et al. (2015) Comparative effectiveness of first-line platinum-based chemotherapy regimens for advanced lung squamous cell carcinoma. Clin Lung Cancer 16: 137-143. [crossref]

16. Ciuleanu T, Stelmakh L, Cicenas S (2012) Efficacy and safety of erlotinib versus chemotherapy in second-line treatment of patients with advanced, non-small-cell lung cancer with poor prognosis (TITAN): a randomised multicentre, open-label, phase 3 study. Lancet Oncol 13:300-8.

\section{Citation:}

Villa JC, Espinosa J, López R, Galan R, Sanchez V, Cervera R, Gómez R. (2017) Platinum Plus Gemcitabine as the Most Effective Regimen in the First Line of Chemotherapy in Advanced Squamous Cell Lung Cancer. Cancer Stud Ther J Volume 2(1): 1-5 